\title{
Prospects for Social and Economic Development of Coal Mining Regions
}

\author{
Elena Kazantseva ${ }^{1, *}$, Natalya Osokina ${ }^{2}$, and Galina Chistyakova ${ }^{1}$ \\ ${ }^{1}$ Plekhanov Russian University of Economics, Kemerovo Institute (branch), 650992 Kuznetsky Av. \\ 39, Kemerovo, Russia \\ ${ }^{2}$ T.F. Gorbachev Kuzbass State Technical University, Institute of Economics and Management, \\ Department of Economics, 650000 Vesennyaya Street 28, Kemerovo, Russia
}

\begin{abstract}
In recent decades, raw materials companies occupy leading positions in world ratings, largely determining the economic situation of their home countries. The rapid growth of digital companies' position in the global economy does not detract from the role of raw materials production, which develops using modern technologies and adheres to the principles of sustainable development. The paper analyzes the position of leading foreign and domestic raw materials companies in the world rankings; examines the features of mining regions functioning, in particular, coal mining regions (on the example of the Kemerovo region, Western Siberia, Russia), and the prospects for their long-term development. Proposals for long-term development of coal mining regions are formulated.
\end{abstract}

\section{Introduction}

The rapid development of digital technology and the fourth industrial revolution substantially change the competitive position of countries and regions. At the same time, the states and territories with significant reserves of demanded mineral resources have a great potential to preserve and even improve their social and economic status in the foreseeable future [1].

This paper is aimed at studying the scale of functioning of mining companies and their role in the development of particular regions, as well as the features and prospects of development of mining regions (on the example of the Kemerovo region, Western Siberia, Russia).

\section{Materials and methods}

The work is based on the analysis of information and analytical materials of the Federal State Statistics Service, the Federal Antimonopoly Service of the Russian Federation, Russian and foreign rating agencies, consulting companies, as well as research results of

\footnotetext{
${ }^{*}$ Corresponding author: 9059655017@mail.ru
} 
V. Kondrat'ev [2], N. Osokina [3], J. Kretschmann [4], M. Ericsson and O. Löf [1], P. Langer [5], etc.

The study is founded on the prerequisites that follow below.

1. The driving force for the development of raw materials regions in the short term is mining industry, which in the narrow sense, is a complex of industries engaged in mining and processing of minerals (polymetallic, copper, lead, aluminum ores, etc., precious metals, iron ore, uranium ores, coal, diamonds, limestone, graphite, asbestos, mica, clay and other mineral building materials). In a broad sense, the mining industry also includes oil and gas production. In this paper, the term "mining industry" is used in the narrow sense with emphasis on the regions where the coal industry is dominant. The development features of the Kemerovo region are considered as an example.

2. Directions for the development of mining regions largely coincide with the general development trends of the "raw materials regions". In the long run, there is an increase in the uncertainty of the prospects for the development of raw materials regions due to the influence of two multidirectional trends. The first trend is related to the effect of factors leading to a long-term reduction in demand for certain types of resources, in particular, coal:

- the decreased use of coal in the electric power industry, the increased use of new energy sources, and the development of "green energy" leads to a decline in demand for traditional types of energy carriers. So, in 2014-2018, coal production in France, Great Britain and Germany was completely stopped, and the substitution of coal generation in the energy balance of European countries continues. The cessation of traditional industries functioning has a mixed impact on the development of former coal mining regions [5, 6];

- the development of new types of materials that reduce the demand for traditional materials and raw materials for their production;

- the development of energy-saving technologies, leading to a more rational use of resources;

- toughening environmental legislation and mass formation of sustainable development ideology;

- a global warming trend;

- the slowdown in economic growth and reduction in resource prices;

- large-scale economic crises, in particular the expected recession, triggered by falling oil prices and a pandemic.

In the global coal industry, a tendency to reduce coal production is forming [4]. According to the Russian Energy Agency of the Energy Ministry of the Russian Federation, in 2013 the global coal industry reached its historic maximum (8270.9 million tons). In 2017 , global coal production decreased by $6.6 \%$. In 2019-2020, there is a fall in prices for energy brands of coal, due to a combination of some factors: decarbonization and the transition to renewable energy sources by most European countries, abnormally warm winters, and a decrease in overall economic activity. The deterioration in economic conditions led to the fact that in 2019, such large American coal mining companies as Cloud Peak Energy and Blackjewel went bankrupt, and the financial situation of Murray Energy and Foresight Energy companies sharply worsened.

The second trend is related to factors that lead to a long-term increase in demand for resources:

- the growth of the world's population and, consequently, resource requirements;

- an increase in living standards of the population, leading to an increase in demand for resources;

- expansion of government support measures for the coal industry, including through regulation of transport tariffs. For example, in Russia, according to the INFOLine-Analytics agency, in the first half of 2019, transport tariffs for coal (202.4 kopecks / $10 \mathrm{t}$-km) were 
several times lower than for three other significant Russian export goods - grain $(434,9$ kopecks / 10 t-km), oil (779.7 kopecks / 10 t-km) and ferrous metals (818.4 kopecks / 10 t$\mathrm{km})$. In March 2020, an agreement between Russian Railways and the Kemerovo region's administration was signed. It ensures the transportation of regional products in 2019-2035 and fixes the guaranteed volumes of coal shipment in the North-West and South directions for a period of one year;

- improvement of transport (railway and port) infrastructure and reduction of transportation costs. Transportation of primary resources has a high share of transport expenses in its cost. According to the Federal Antimonopoly Service of the Russian Federation, the share of transport costs in the final price of coal in certain directions reaches more than $60 \%$. At the same time, primary resources transportation has a significant share in the volume of freight. Thus, the coal industry accounts for $45 \%$ of the total freight turnover of the Russian railway;

- a shift in demand growth towards consumers from China, South Korea and Japan.

In addition, there are a number of factors that contribute to the movement of resource centers within countries and on a global scale. In the latter case, we are talking about reducing the volume of resource mining in economically developed countries striving for ensuring control over a reliable supply of raw materials. Control over resources is one of the most significant elements of the redistribution of power in the modern world-system, and the resources themselves serve to accelerate the economic growth of competing countries-leaders [3]. The movement of developed countries towards abandoning of extractive industries is associated with the desire for the environment status improvement and the conservation of certain resources.

\section{Results and discussion}

Currently, mining on a global scale is an important element that ensures the economic development of resource-producing regions and countries. The leading positions of global raw materials companies in the world rankings are maintained. In the "Fortune Global 500" ranking for 2019 (based on the results of 2018), the top ten in terms of revenue included: Sinopec Group (China, 2nd place); Royal Dutch Shell (Great Britain, Netherlands, 3rd place); China National Petroleum (China, 4th place); Saudi Aramco (Saudi Arabia, 6th place), BP (UK, 7th place); Exxon Mobil (USA, 8th place). It is worth mentioning that all the leading companies in the rating were oil and gas companies. The rating also included three Russian raw materials companies: Gazprom (42nd place), Lukoil (50th place), Rosneft Oil (86th place).

The 2019 Forbs ranking "The World's Largest Public Companies" (at the year-end 2018) in terms of market capitalization included: oil companies - ExxonMobil (USA), Royal Dutch Shell (Netherlands), Chevron (USA), PetroChina (China), BP (UK), etc.; and some mining companies - Newmont Mining (USA), Saudi Arabian Mining (Saudi Arabia), Sumitomo Metal Mining (Japan), Yanzhou Coal Mining (China), Zijin Mining Group (China).

The positions of leading mining companies are analyzed in more detail in specialized studies. According to the PwCIL review "Mining Industry, 2019. Resources for the Future", among the forty largest mining companies in the world (in terms of market capitalization), the leaders are: BHP Group Limited (Australia, UK, diversified company, 1st place); Rio Tinto Limited (Australia, UK, diversified company, 2nd place); Vale S. A. (Brazil, diversified company, 3rd place); Glencore Plc (Switzerland, diversified company, 4th place); China Shenhua Energy Company Limited (China, Hong Kong, coal, 5th place). 
Of the forty companies listed in the rating, six are coal mining companies. The rating includes the following Russian mining companies: PMN "Russian Nickel" (Nickel, 6th place), Alrosa (diamonds, 22nd place), Polymetal International plc (gold, 36th place).

PwCIL experts note that the confidence of investors and consumers in the mining industry is falling due to doubts about the ability of the industry to develop sustainably and create benefits for all stakeholders. Safety and environment incidents played a significant role in forming this opinion. Over the past 15 years, there has been a slight increase in the market capitalization of mining companies, in contrast not only to the new technology sector, but also to raw materials industries such as oil and gas industry.

More than 60 countries are producing coal globally on an industrial scale, the first ten of which account for $90 \%$ of global coal production. According to the Ministry of Energy of the Russian Federation, as of the beginning of 2019, 166 coal enterprises, including 57 mines and 109 opencast mines, were producing coal in the country.

From 2008 to 2018, the volume of Russian coal production increased by more than $30 \%$, investment in fixed assets of coal enterprises went up 2.5 times. During this time period, domestic enterprises have introduced 300 million tons of new coal mining capacities (at the same time, 188 mines and 15 open-pit mines were closed in 25 years). Labor productivity has increased 1.5 times since 2008. The development of traditional centers of coal mining in Western and Eastern Siberia and coal deposits in the Far East and in the Arctic zone continued (Source: https://www.eg-online.ru/article/405427/).

More than half of coal output in Russia is exported, which explains the sensitivity of the industry to fluctuations in external demand. Traditionally, about $60 \%$ of Russian coal is mined in Kuzbass, which exports coal to more than 60 countries. The main centers of Kuzbass coal mining are concentrated in Mezhdurechensk, Leninsk-Kuznetsk, Belovo, Novokuznetsk, as well as in Kemerovo, Belovsky, Prokopevsky and Novokuznetsk regions.

According to the data presented in the RAEX-600 report for 2019, the coal industry kept on developing in 2018 (total revenue growth was 37.8\%), which strengthened Russia's position as the sixth largest global producer (with a share of 5.3\%). The volume of coal exports from Russia also reached record levels, which in 2018 increased by $10.6 \%$ to 210.3 million tons; in value terms, the growth was $26.1 \%$ and reached $\$ 17.6$ billion.

Coal companies play a significant role in the development of Russian regions. A number of studies have been devoted to assessing the role of large mining companies in the Kemerovo region, including the work of O. N. Kovkhaeva, E. O. Pakhomova et al [7].

The 2019 RAEX-600 rating included twelve coal mining companies, ten of which showed revenue growth above the average for the list as a whole. The Kemerovo region is represented in the ranking by the following coal companies: Stroyservis (150th place), Sibuglemet (199th place), Kuzbass Fuel Company (206th place), Mezhdurechye (326th place), Berezovsky open-pit mine (384th place), Chernigovets (399th place), Mine Office "Mayskoye" (435th place), Coal, production and trading company (519th place), Resource (524 place). In addition, the SUEK Company (26th place) operates in the Kemerovo region.

Coal mining companies keep their significance at present. For example, in 2018, SUEK paid \$ 633 million in taxes in Russia, and also allowed \$ 38 million for social and charitable projects (the data are presented on the company's official website). At the end of 2018, the company was the largest taxpayer in the Kemerovo region. According to the results of the largest taxpayers performance assessment (at the year-end 2018), conducted by the Publishing House "Kommersant", the income tax of SUEK amounted to 5433 million rubles, which is $8.1 \%$ of the total income tax received in the regional budget. The company follows a sustainable development policy and generates relevant reports. The company's social programs are implemented in more than 60 settlements of Russian regions. In total, during 2018, SUEK carried out more than 220 social and charitable projects in 11 regions. 
The enterprise group AO "Stroyservis" has been signing agreements on social and economic cooperation with the Kemerovo region administration for 15 years. In 2018, under this agreement, 603 million rubles were allocated to regional social programs (the data are presented on the company's official website). Other leading coal companies (SDSUgol, Sibuglemet, etc.) also participate in the implementation of social projects.

Despite a significant role in ensuring the country's energy security [8], developing regions, and strengthening export potential, coal mining regions, in particular, the Kemerovo region, still have lower indicators of socio-economic development, not only in comparison with the regions where the oil and gas industry is based, but also on national average. Uneven regional development is one of the factors that negatively affect the economic security of both lagging regions and the country as a whole [9].

According to the Federal State Statistics Service, during 2005-2018, the growth rate of the physical volume of Russian GDP exceeded the growth rate of the physical volume of GRP in the Kemerovo region (with the exception of 2009, 2014, 2017). Growth trends in gross value added of minerals mining in the Russian Federation and the Kemerovo region are not so clear. There are periods of outperforming growth rates of gross value added of mining in the Russian Federation compared to the Kemerovo region (2008-2013, 2015, 2018), and vice versa (see Table 1).

Table 1. Growth rates of physical volume of GDP (GRP of the Kemerovo region) and growth rates of gross value added of mining in the Russian Federation and the Kemerovo region, percent.

\begin{tabular}{|c|c|c|c|c|}
\hline \multirow[b]{2}{*}{ Year } & \multicolumn{2}{|c|}{ the Russian Federation } & \multicolumn{2}{|c|}{ the Kemerovo region } \\
\hline & $\begin{array}{c}\text { Growth rate of } \\
\text { physical volume } \\
\text { of GDP }\end{array}$ & \begin{tabular}{|c|} 
Growth rates of \\
gross value added \\
of minerals mining
\end{tabular} & $\begin{array}{c}\text { Growth rates of } \\
\text { the physical } \\
\text { volume of GRP }\end{array}$ & $\begin{array}{c}\text { Growth rates of } \\
\text { gross value added } \\
\text { of minerals mining }\end{array}$ \\
\hline 2005 & 107.6 & 104.7 & 106.8 & 105.3 \\
\hline 2006 & 108.3 & 104.6 & 107.2 & 108.9 \\
\hline 2007 & 111.2 & 103.1 & 106.8 & 105.5 \\
\hline 2008 & 105.7 & 100.3 & 102.1 & 100.0 \\
\hline 2009 & 92.4 & 98.6 & 92.9 & 97.7 \\
\hline 2010 & 104.6 & 106.9 & 102.7 & 105.0 \\
\hline 2011 & 105.4 & 104.6 & 102.3 & 103.6 \\
\hline 2012 & 103.1 & 100.2 & 95.8 & 89.8 \\
\hline 2013 & 101.8 & 101.2 & 96.0 & 95.6 \\
\hline 2014 & 101.3 & 100.4 & 102.1 & 102.1 \\
\hline 2015 & 99.4 & 102.5 & 99.0 & 101.7 \\
\hline 2016 & 100.8 & 102.8 & 97.0 & 106.3 \\
\hline 2017 & 101.8 & 102.2 & 102.5 & 103.6 \\
\hline 2018 & 102.8 & 106.0 & 101.9 & 101.6 \\
\hline
\end{tabular}

Comparing the growth rate of the physical volume of GDP and the growth rate of the gross value added of minerals mining, we conclude that in 2009-2011 and the last five years, the growth rate of minerals mining was faster. In the Kemerovo region, outperforming growth rates of minerals mining compared to the growth rate of GRP were observed in 2006, 2009-2011 and in 2015-2017. In 2005-2018, the gross value added of minerals extraction in the Russian Federation increased by 1.45 times, and in the Kemerovo region went up by 1.28 times. 
The share of minerals mining in the sectoral structure of gross value added of the Kemerovo region varied from $20.6 \%$ (in 2004) to $36.7 \%$ (in 2018), while in the Russian Federation these parameter changed from $9.7 \%$ (in 2009) to $14.8 \%$ (in 2018), which indicates an increasing role of extractive industries in the production of GDP and GRP (see Figure 1). In 2004-2015, the GRP structure is presented by economic sectors according to the OKVED-2007 (Russian Classification of Economic Activities). In the Kemerovo region, the share of the mining sector is significantly higher than the national average.

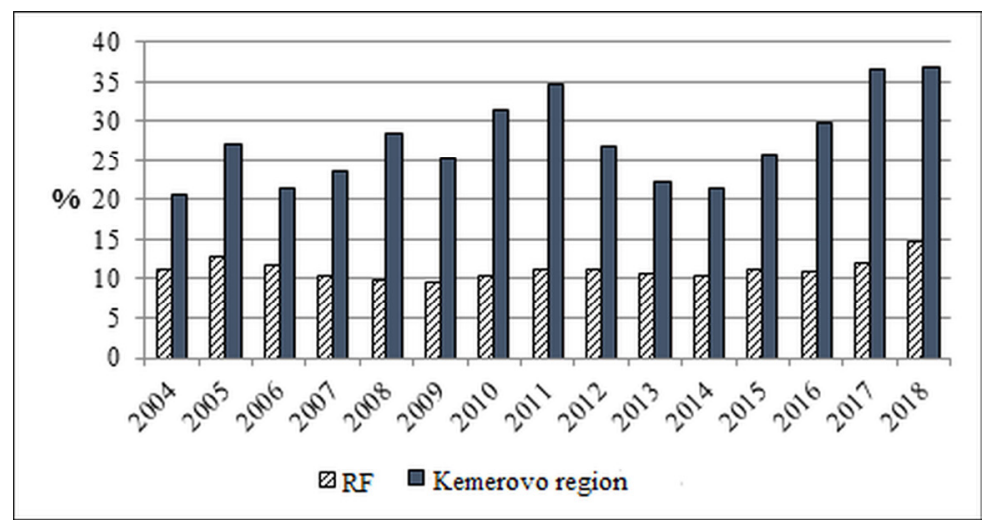

Fig. 1. Share of minerals mining sectoral structure of gross value added in the Russian Federation and Kemerovo region at current prices, as a percentage of total.

In the Kemerovo region there is a higher proportion of unprofitable enterprises and organizations compared to the national average. Figure 2 illustrates this situation for 20102018. Coal demand in 2019 was characterized by downward trends. The decline in the growth rate of coal mining is associated with a decrease in coal prices on world markets. So, as noted by S. E. Tsivilev, the Governor of the Kemerovo region-Kuzbass, in his Budget message of 2019, in November 2019, prices for energy grades of coal fell by $44 \%$ to the level of November 2018, for coking grades - by almost a quarter. In 2019, the share of unprofitable enterprises and organizations in the Kemerovo region was $31.2 \%$, while the share of unprofitable enterprises engaged in coal mining increased to $42.2 \%$ (against $30 \%$ in 2018).

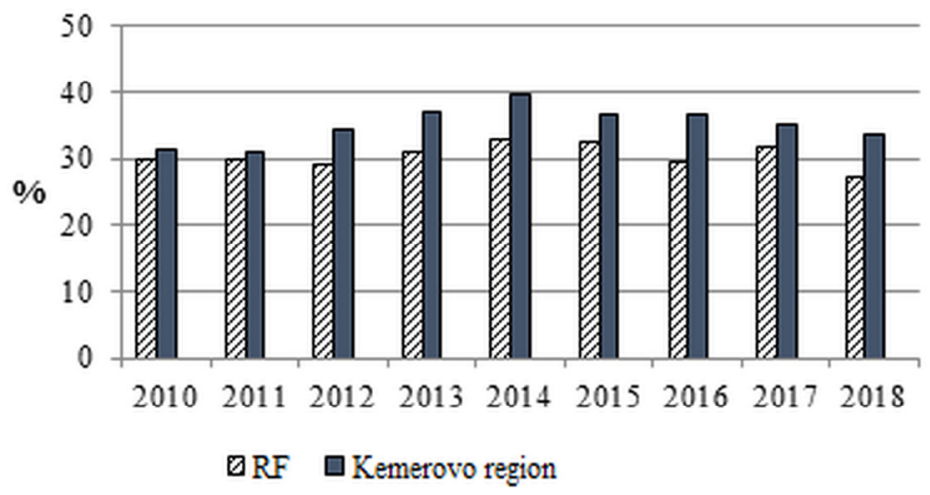

Fig. 2. Share of unprofitable enterprises and organizations in the Russian Federation and Kemerovo region, as a percentage of total.

Despite the challenging situation with coal prices, in 2019, the volume of investments in the Kuzbass coal industry development amounted to about 105 billion rubles, which is 7.7 
billion rubles more than in 2018. 85 billion rubles $(81 \%)$ of the total investment resources were allocated for technical re-equipment and reconstruction of existing enterprises of the Kuzbass coal industry, and 20 billion rubles (19\%) were spent for the construction of new coal industry facilities [Source: https://ako.ru/news/detail/itogi-2019-goda-].

Most mining regions have a tense environmental situation. There is no doubt that not only mining enterprises, but also companies of metallurgical, chemical and other industries have a negative effect on the environment. The Kemerovo region is no exception. In the Strategy for social and economic development of the Kemerovo region until 2035, it is noted that the coal industry accounts for about $60 \%$ of all emissions. During 2010-2017, emissions of air pollutants from stationary sources in relation to 2007 in the Kemerovo region exceeded the national average (see Figure 3). At the same time, the share of captured and neutralized air pollutants in the total amount of waste pollutants from stationary sources in the Kemerovo region is traditionally higher than the national average.

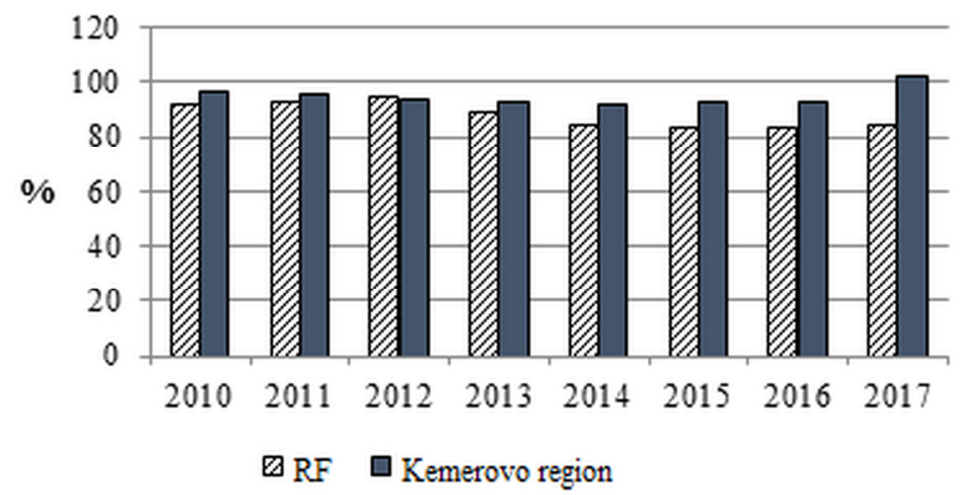

Fig. 3. Emissions of air pollutants from stationary sources in relation to 2007.

The ultimate goal of socio-economic systems activity is to improve the level and quality of life of the population. In this regard, we will focus on the indicators of the size and dynamics of wages and the level of poverty, as measured by the indicators "the share of the population with incomes below the subsistence minimum".

As for the size and dynamics of wages, in 2004-2019, the average salary in the country increased 7 times (from 6,740 to 47,468 rubles), and in the Kemerovo region - 7.9 times (from 5,264 to 41684 rubles), while in 2019, the average salary in the Kemerovo region was $87.8 \%$ of the national average. In the Kemerovo region the share of the population with incomes below the subsistence minimum is steadily higher than the average for the Russian Federation. The average Russian and Kuzbass indicators for the years were: in 2013 $10.8 \%$ and $13.9 \%$, in $2014-11.3 \%$ and $14.1 \%$, in $2015-13.4 \%$ and $15.8 \%$, in $2016-$ $13.2 \%$ and $15.9 \%$, in $2017-12.9 \%$ and $15.9 \%$.

The registered unemployment rate in the Kemerovo region has been slightly higher than the national average over the past few years. The high dependence of the regional economy on the global market conditions poses additional risks of worsening the economic situation of employees. So, according to the Federal State Statistical Service in February 2020, the region became the leader in the volume of overdue wage arrears - 268.1 million rubles (almost $12 \%$ of the total wage arrears in the Russian Federation). During the month, the debt increased by $171.7 \%$. The reason for the debt increase lies in the lack of equity capital of enterprises and organizations.

The uncertain economic situation of 2020 increases the risks for the mining regions development, in particular, the Kemerovo region. In these conditions, there is a heavy need in the state support for the enterprises and organizations of the sectors most affected by the 
introduction of restrictive measures, as well as for monotown enterprises, on the one hand, and diversification of the economy, on the other.

\section{Conclusion}

The analysis of trends in the development of raw materials industries suggests a possible long-term decline in demand for certain resources, in particular coal, which requires reforming both the mining sector, primarily the coal industry, and creating and developing new industries in coal mining regions.

According to the Strategy for social and economic development of the Kemerovo region until 2035, in the medium term, the coal industry will continue to play a significant role in the investment, production and financial sectors of the Kemerovo region. During this period, it is possible to search for new markets, improve the activities of coal enterprises, and introduce modern technologies aimed at improving labor productivity and environmental safety.

Taking into account the possible reduction in demand for coal in the long term, to ensure a high level of socio-economic development of the region, it is necessary to focus both on developing traditional economic activities, and forming new directions:

- diversifying activities and stimulating investments throughout the value chain $[2,10]$;

- forming new types of economic activity in the manufacturing field;

- developing the field of information technology, biotechnology, nanotechnology, medicine, and education;

- introducing digital technologies in the development of traditional industries; transition to the "Industry 4.0" model, accompanied by changes in qualification requirements, computerization of workplaces, digitization and digital integration of production processes, and the use of digital networks to coordinate economic interaction; and so on;

- creating new social institutions aimed at developing collective tools for regulating labour relations (evaluating the performance of employers, social policies of companies, creating common employment databases, platforms for reviews of employers, co-working sites, etc.) and functioning in the conditions of workforce ageing;

- following the concept of sustainable development, greening production, improving the level of labour safety, including the introduction of digital systems for monitoring, alerting and searching people.

This will increase the adaptive capacity of the region with respect to both long-term changes in demand for resources and unpredictable external shocks. Ultimately, following modern development trends will increase the level and quality of life of the population.

\section{References}

1. M. Ericsson, O. Löf, Mineral Economics, 32, 223-250 (2019)

2. V. B. Kondrat'ev, World Economy and International Relations, 60/1, 41-52 (2016)

3. N. Osokina, E3S Web Conf., 41, 04032 (2018)

4. J. Kretschmann, Mining, Metallurgy \& Exploration, 37, 167-178 (2020)

5. P. Langer, IOP Conf. Ser.: Mater. Sci. Eng., 471, 112003 (2019)

6. P. D. Saundry, Energy, Sustainability and Society, 9, 4 (2019)

7. O. N. Kavkaeva, E. O. Pakhomova, E. V. Goosen, S. M. Nikitenko, G. A. Chakhoyan, IOP Conf. Ser.: Earth Environ. Sci., 262, 012025 (2019)

8. S. A. Zhironkin, A. A. Khoreshok, M. A. Tyulenev, G. A. Barysheva, M. C. Hellmer, IOP Conf. Ser.: Mater. Sci. Eng., 142, 012127 (2016) 
9. E. Kazantseva, G. Chistyakova, E3S Web Conf., 41, 04045 (2018)

10. V. B. Kondrat'ev, V. V. Popov, G. V. Kedrova, World Economy and International Relations, 64:3, 68-79 (2020) 